\title{
Geographical Distribution of Allelic Variations of Enzymes in Chum Salmon Oncorhynchus keta, River Populations of Japan and the Effects of Transplantation
}

\author{
Toshio OKAZAKI*
}

(Received April 5, 1982)

\begin{abstract}
Allelic frequencies of fourteen polymorphic loci were compared among chum salmon populations returning to forty-three rivers in Japan.

The study on genetic similarity revealed two major clusters of (1) Okhotsk and Nemuro and (2) East of Cape Erimo regional populations in Hokkaido and (1) northern and (2) southern regional populations both on the Pacific coast and the Japan Sea coast of Honshu. The division occurs at the middle of Iwate Prefecture on the Pacific coast and at the northern part of Niigata Prefecture on the Japan Sea coast.

The common genetic feature is still observed despite the frequent transplantations attempted to date, which suggests there is no noticeable effects of planting.
\end{abstract}

Chum salmon accounts for major portion of salmonid fishes returning to rivers and streams in Japan. Its distribution extends from Hokkaido in north to the middle of Honshu in south which corresponds to the southern limits of chum salmon distribution in Asia. ${ }^{12}$

Precise homing behavior is supported for salmonid fishes. If chum salmon indeed home with precision, then each river should have its own particular genetic populations. Chum salmon attracts much attention partly because it has commercial importance as the stock is largely maintained through hatcheries and partly because it provides the most adequate material for the population study of fish. Morphology and tagging activities have been the major tools for the previous population studies of chum salmon, whereas in recent years the emphasis has been laid on biological genetic methods which offer numerous advantages for population studies.

OKAZAKI ${ }^{2)}$ studied the chum salmon populations in North America and noted that the allelic frequencies are similar among the proximal river populations. He concluded that this is due to genetic intermingling having continued for generations. He further pointed out that river populations in the Continent of North America make up several regional populations. The genetic study of chum salmon populations in Japan was investigated by NuMACHI and $\mathrm{SATO}^{3)}$ and Kujma and Fusio.) However, due to frequent transplantations associated with artificial propa- gation, almost all the rivers have been planted in Japan. Therefore due consideration needs to be given to the effects produced on the frequencies of alleles of the native stocks.

The present report examines the population structure of chum salmon in Japan as well as its genetic feature through the analysis of forty-three river populations throughout the entire distribution of chum salmon in Japan. The problem of transplantation and its actual effects are also discussed.

The author wishes to express many thanks to the former Prof. K. Mizue and Assoc. Prof. K. NUMACH, Ocean Research Institute, University of Tokyo, for valuable advice and encouragement. Thanks are also due to Mr. Y. TAKAHASHI, Japan Sea Regional Fisheries Research Laboratory and Mr. H. Mayama, Hokkaido Salmon Hatchery, for their kind offices for sampling. The author is also indebted to Messrs. K. KawASAKI, Y. NAGAHORA and M. KAERIYAMA for supplying the samples.

\section{Materials and Methods}

Sample locations of forty-three rivers are identified in Fig. 1 and sample size and dates of collection are listed in Table 2. Parental fish returning to each river or their fry were used as samples. Whole fish body or tissues of liver, heart, muscle and eyeball were frozen immediately following collection until processed for experi-

* Far Seas Fisheries Research Laboratory, 1000 Orido, Shimizu 424, Japan (岡㱦登志夫: 透洋水産研究所). 


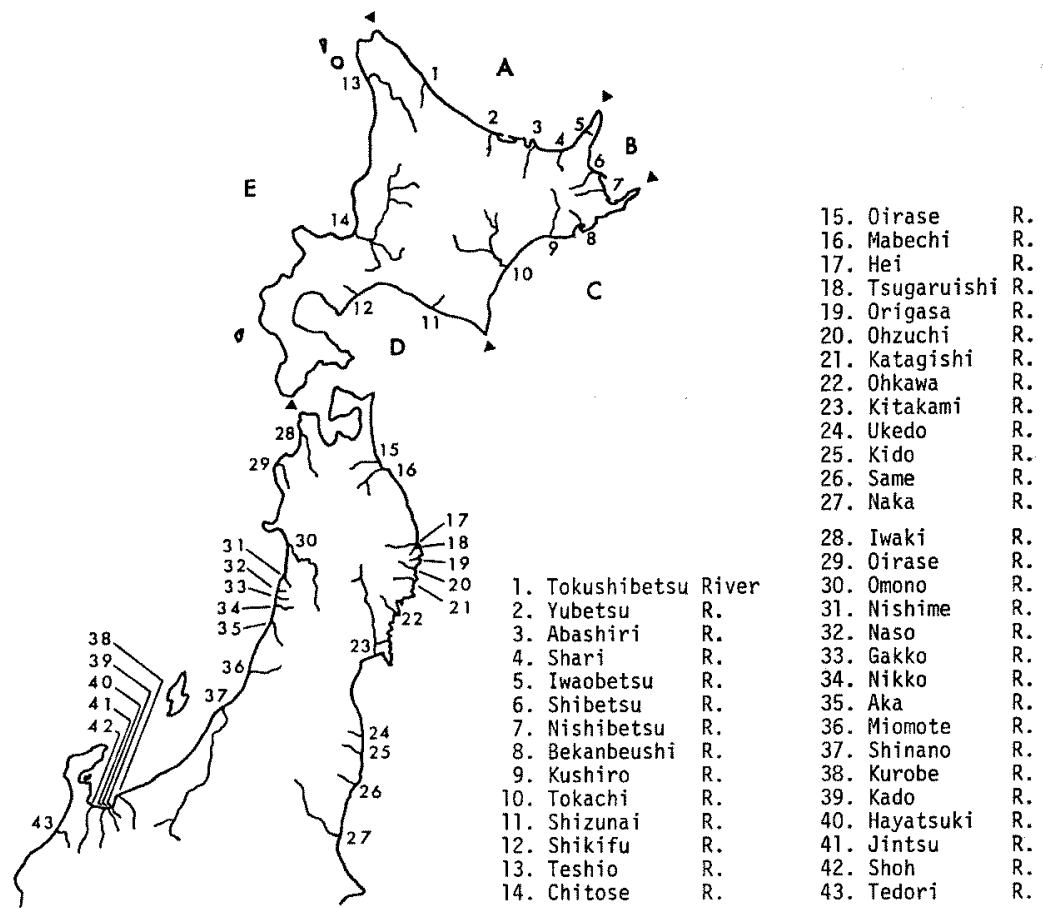

Fig. 1. Map of Japan showing the rivers where chum salmon were sampled. A) Okhotsk area, B) Nemuro area, C) East of Cape Erimo area, D) West of Cape Erimo area, E) Japan Sea area.

A: boundary of each area.

ments. Genetic data were collected from analysis of fourteen enzymes. Staining procedures followed methods outlined in Siclliano and SHAw. ${ }^{\text {s) }}$

\section{Results}

Genetic variants were identified in fourteen loci coding ten out of fourteen analyzed enzymes (Table 1). The variant alleles of the fourteen loci of chum salmon have been already reported in the previous paper. ${ }^{2}$

Table 2 shows the allelic frequencies of each examined river population. Each river population is polymorphic for AAT-3 and IDH-2 at high frequencies, whereas the frequency decreases for other genetic loci. However almost all the river populations are polymorphic for LDH-1 and MDH-B. The above characteristics distinguish the examined populations from those returning to the Continent of North America and other areas as will be discussed later. The genetic structure of the river populations in the respective areas of Hokkaido and the Pacific coast and the
Japan Sea coast of Honshu is discussed in the following section.

\section{Hokkaido}

Hokkaido is divided by five capes and rivers situated in between these capes make up one "area" (Fig. 1). This unit of "area" well reflects the ecological feature of chum salmon. For example, chum salmon population in different area is distinguishable by different returning period. the East of Cape Erimo area

$$
\text { late September late October }
$$

the West of Cape Erimo area

$$
\text { early October -late November }
$$

the Japan Sea area

$$
\text { early October -late October }
$$

the Nemuro area

the Okhotsk area

$$
\text { middle November -early December }
$$

late November -middle December

However, the distinct feature by area was not observed in the allelic frequencies of the examined river populations. This presumably is a result of 
Table 1. Enzymes stained for, abbreviation, locus designation, tissue distribution and number of alleles

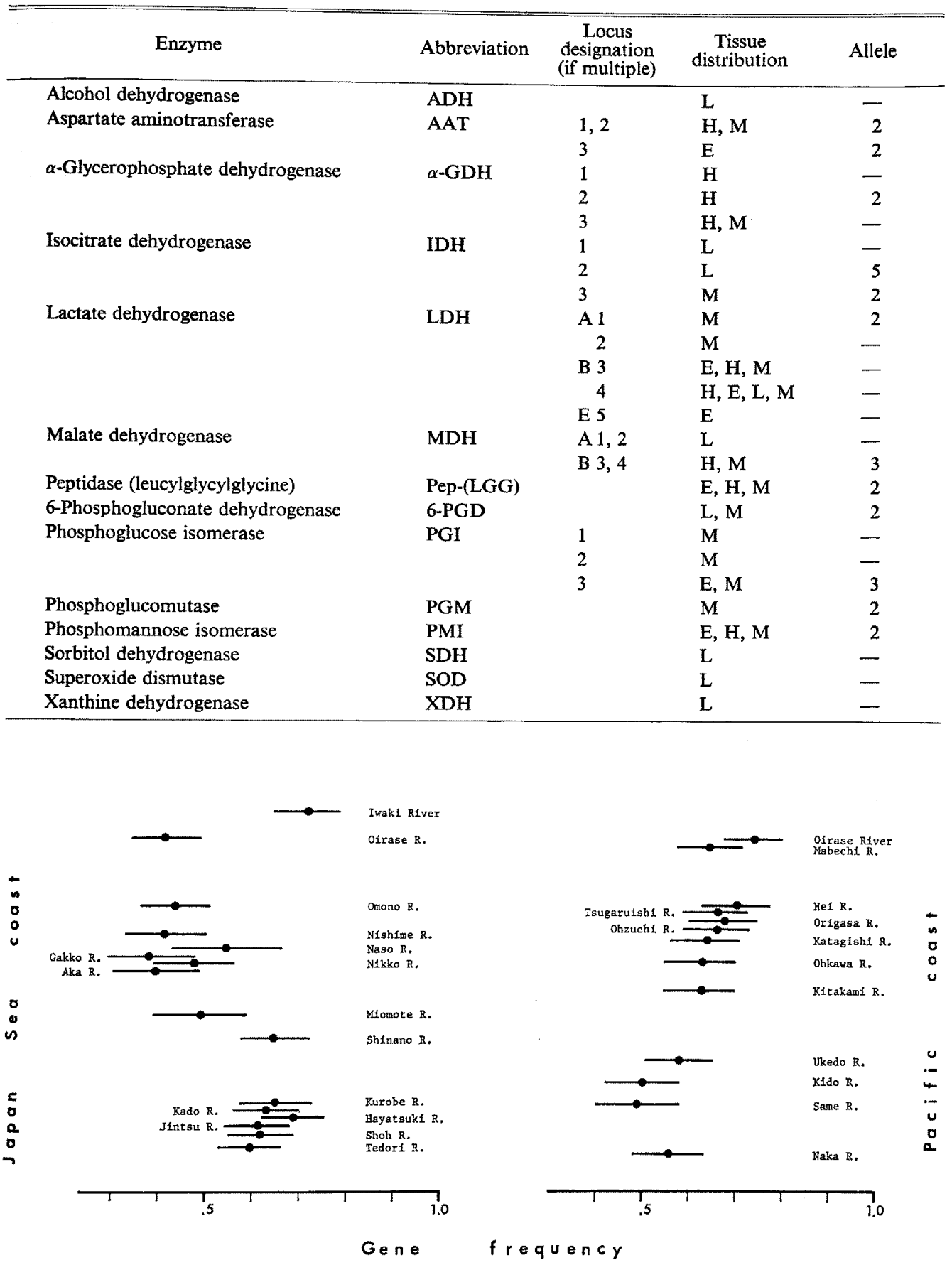

Fig. 2. Distribution of allelic frequencies and $95 \%$ confidence intervals of the $1 d h-2-a$ allele in river populations on the Pacific and the Japan Sea coasts of Honshu. 
Table 2. Gene frequencies at each locus in river

\begin{tabular}{|c|c|c|c|c|c|c|c|c|c|c|c|c|c|}
\hline \multirow{2}{*}{ River } & \multirow{2}{*}{$\begin{array}{l}\text { Collected } \\
\text { date }\end{array}$} & \multirow{2}{*}{$\begin{array}{c}\text { Sample } \\
\text { size }\end{array}$} & \multicolumn{2}{|c|}{$\mathrm{AAT}-1,2$} & \multicolumn{2}{|c|}{ AAT-3 } & \multicolumn{2}{|c|}{$\alpha$-GDH-2 } & \multicolumn{5}{|c|}{ IDH-2 } \\
\hline & & & $a$ & $b$ & $a$ & $b$ & $a$ & $b$ & $a$ & $b$ & $c$ & $d$ & $e$ \\
\hline \multicolumn{14}{|l|}{ Hokkaido } \\
\hline Tokushibetsu & Apr. & $100(\mathrm{~J})$ & - & 一 & - & 一 & - & - & .527 & .287 & .027 & .160 & .000 \\
\hline Yubetsu & Nov, 25,771 & $100(\mathrm{M})$ & - & - & - & - & .990 & .010 & .480 & .395 & .025 & .080 & .020 \\
\hline Abashiri & Nov. 27,771 & $100(\mathrm{M})$ & - & - & - & - & .985 & .015 & .490 & .381 & .046 & .062 & .021 \\
\hline Shari & Nov. 26, 771 & $100(\mathrm{M})$ & 一 & - & - & - & .985 & .015 & .439 & .408 & .061 & .082 & .010 \\
\hline Iwaobetsu & Apr. $\quad 791$ & $100(\mathrm{~J})$ & - & - & - & - & - & - & .433 & .346 & .019 & .202 & .000 \\
\hline Shibetsu & Nov. 29,771 & $100(\mathrm{M})$ & - & - & - & - & .970 & .030 & .505 & .414 & .020 & .056 & .005 \\
\hline Nishibetsu & Dec. 1,77 & $99(\mathrm{M})$ & - & - & - & - & .975 & .025 & .469 & .388 & .026 & .102 & .015 \\
\hline Bekanbeushi & Oct. 14,771 & $100(\mathrm{M})$ & - & - & - & - & .985 & .015 & .510 & .272 & .000 & .218 & .000 \\
\hline Kushiro & Oct. 13,771 & $100(\mathrm{M})$ & - & - & - & - & .920 & .080 & .515 & .318 & .020 & .146 & .000 \\
\hline Tokachi & Oct. 12,771 & $100(\mathrm{M})$ & - & - & - & - & .985 & .015 & .530 & .435 & .010 & .025 & .000 \\
\hline Shizunai & Apr. & $100(\mathrm{~J})$ & - & - & - & - & - & - & .526 & .417 & .000 & .058 & .000 \\
\hline Shikifu & Apr. & $100(J)$ & 一 & - & - & - & - & - & .539 & .344 & .006 & .110 & .000 \\
\hline Teshio & Apr. & $91(\mathrm{~J})$ & - & - & - & - & - & - & .539 & .402 & .010 & .049 & .000 \\
\hline Chitose & Oct. 15,771 & $100(\mathrm{M})$ & .944 & .056 & .701 & .299 & .975 & .025 & .606 & .328 & .010 & .056 & .000 \\
\hline \multicolumn{14}{|l|}{ Honshu } \\
\hline \multicolumn{14}{|l|}{ Pacific coast } \\
\hline Oirase & Mar. 3,81 1 & $100(\mathrm{~J})$ & 一 & - & .600 & .400 & - & 一 & .739 & .250 & .000 & .011 & .000 \\
\hline Mabechi & Feb. 26,811 & $100(\mathrm{~J})$ & - & - & .672 & .328 & - & - & .644 & .316 & .017 & .023 & .000 \\
\hline Hei & Mar. 14, 80 & $92(\mathrm{~J})$ & - & 一 & .774 & .226 & - & - & .703 & .279 & .017 & .000 & .000 \\
\hline Tsugaruishi & Mar. 14,801 & $100(\mathrm{~J})$ & 一 & - & .582 & .418 & - & - & .663 & .320 & .006 & .012 & .000 \\
\hline Origasa & Mar. 14, 801 & $100(\mathrm{~J})$ & .979 & .021 & .779 & .221 & - & - & .680 & .280 & .020 & .020 & .000 \\
\hline Ohzuchi & Mar. 14,801 & $100(\mathrm{~J})$ & - & - & .717 & .283 & - & 一 & .663 & .308 & .029 & .000 & .000 \\
\hline Katagishi & Mar. 14, 801 & $100(\mathrm{~J})$ & - & - & .679 & .321 & - & 一 & .638 & .259 & .011 & .092 & .000 \\
\hline Ohkawa & Mar. $\quad 801$ & $100(\mathrm{~J})$ & - & - & .673 & .327 & - & - & .631 & .363 & .006 & .000 & .000 \\
\hline Kitakami & Mar. & $100(\mathrm{~J})$ & - & - & .750 & .250 & - & - & .626 & .351 & .011 & .011 & .000 \\
\hline Ukedo & Feb. $\quad 7,801$ & $100(\mathrm{~J})$ & - & - & - & - & - & - & .583 & .383 & .000 & .033 & .000 \\
\hline Kido & Feb. 8,811 & $100(\mathrm{~J})$ & - & - & .646 & .354 & - & - & .500 & .486 & .000 & .014 & .000 \\
\hline Same & Feb. 8,811 & $100(J)$ & - & - & .855 & .145 & - & 一 & .491 & .491 & .000 & .019 & .000 \\
\hline Naka & Feb. 8,811 & $100(J)$ & - & - & .813 & .188 & - & - & .558 & .416 & .006 & .019 & .000 \\
\hline \multicolumn{14}{|c|}{ Japan Sea coast } \\
\hline Iwaki & Mar. 17, 811 & $100(J)$ & - & - & .616 & .384 & - & - & .717 & .250 & .011 & .022 & .000 \\
\hline Oirase & May. 2, 80 & $100(\mathrm{~J})$ & - & - & - & - & 一 & - & .414 & .414 & .092 & .080 & .000 \\
\hline Omono & Mar. $\quad 801$ & $100(\mathfrak{J})$ & - & - & - & - & 一 & - & .432 & .414 & .074 & .080 & .000 \\
\hline Nishime & Mar. & $99(\mathrm{~J})$ & - & - & .548 & .452 & - & - & .412 & .551 & .022 & .015 & .000 \\
\hline Naso & Mar. 31,80 & $100(J)$ & - & - & - & - & - & - & .544 & .412 & .044 & .000 & .000 \\
\hline Gakko & Mar. 24, 80 & $96(\mathbf{J})$ & - & - & - & - & - & - & .380 & .598 & .000 & .022 & .000 \\
\hline Nikko & Mar. & $100(J)$ & - & - & - & - & - & 一 & .475 & .467 & .042 & .017 & .000 \\
\hline Aka & Dec. 3,80 & $49(\mathrm{M})$ & 1.000 & .000 & .804 & .196 & 1.000 & .000 & .394 & .521 & .053 & .032 & .000 \\
\hline Miomote & Mar. $\quad 791$ & $100(\mathrm{~J})$ & - & 一 & .707 & .293 & - & - & .489 & .447 & .011 & .053 & .000 \\
\hline Shinano & Mar. 12, 80 & $100(\mathrm{~J})$ & - & - & - & - & - & - & .646 & .268 & .018 & .067 & .000 \\
\hline Kurobe & Feb. $\quad 81$ & $100(\mathrm{~J})$ & - & - & .636 & .364 & - & - & .655 & .275 & .035 & .035 & .000 \\
\hline Kado & Mar. 4, 80 & $100(\mathrm{~J})$ & - & - & .587 & .413 & 一 & - & .630 & .250 & .016 & .103 & .000 \\
\hline Hayatsuki & Feb. 23, 81 & $100(J)$ & - & - & .661 & .339 & - & 一 & .687 & .247 & .049 & .016 & .000 \\
\hline Jintsu & Feb. & $100(\mathrm{~J})$ & - & - & .730 & .270 & 一 & - & .617 & .300 & .072 & .011 & .000 \\
\hline Shoh & Feb. & $100(\mathrm{~J})$ & - & - & .506 & .494 & 一 & 一 & .621 & .328 & .023 & .029 & .000 \\
\hline Tedori & Oct. Nov. 79 & $103(\mathrm{M})$ & - & - & - & 一 & .985 & .015 & .597 & .272 & .097 & .034 & .000 \\
\hline
\end{tabular}


populations of chum salmon in Japan

\begin{tabular}{|c|c|c|c|c|c|c|c|c|c|c|c|c|c|c|c|c|c|}
\hline \multicolumn{2}{|c|}{ IDH-3 } & \multicolumn{2}{|c|}{ LDH-1 } & \multicolumn{3}{|c|}{ MDH-B } & \multicolumn{2}{|c|}{ Pep-(LGG) } & \multicolumn{2}{|c|}{ 6-PGD } & \multicolumn{3}{|c|}{ PGI-3 } & \multicolumn{2}{|c|}{ PGM } & \multicolumn{2}{|c|}{ PMI } \\
\hline$a$ & $b$ & $a$ & $b$ & $a$ & $b$ & $c$ & $a$ & $b$ & $a$ & $b$ & $a$ & $b$ & $c$ & $a$ & $b$ & $a$ & $b$ \\
\hline- & - & & & & & & & & & & & & & & & & \\
\hline - & - & .947 & .0 & .980 & .013 & .008 & & .000 & .995 & .005 & & & .000 & & .000 & & .00 \\
\hline - & 一 & .874 & .1 & .975 & .023 & 3 & & & & & & 0 & 0 & & .000 & .990 & .010 \\
\hline- & - & .854 & & .970 & .0 & .003 & & .0 & .9 & & & 0 & .000 & & 00 & 95 & .00 \\
\hline- & - & .949 & .051 & .986 & .0 & .000 & & .000 & .993 & .0 & 00 & .000 & .000 & & .000 & 0 & .00 \\
\hline .820 & .180 & .849 & .151 & .983 & .008 & .010 & 0 &. & 5 & 5 & 95 & & & & .005 & .985 & .015 \\
\hline .885 & .11 & .843 & & .9 & .020 & .003 & & .0 & & .0 & & & .000 & & .000 & .954 & .04 \\
\hline .919 & .081 & .890 & & .96 & & .000 & & & 1.0 & .000 & 1. & .000 & .000 & 00 & .000 & .990 & .01 \\
\hline- & - & .903 & .097 & .968 & .033 & .000 & 1.000 & .000 & 1.000 & .000 & 1.000 & .000 & .000 & 00 & .000 & .990 & .01 \\
\hline .831 & .169 & .829 & & .973 & .028 & .000 & & .014 & .985 & .015 & 1.000 & .000 & .000 & 1.000 & .000 & .965 & .03 \\
\hline- & - & .915 & .085 & .990 & .007 & .003 & 1.000 & .000 & 1.000 & .000 & 1.000 & .000 & .000 & 1.000 & .000 & .975 & .02 \\
\hline- & - & .911 & .089 & .975 & .025 & .000 & 1.000 & .000 & 1.000 & .000 & 1.000 & .000 & .000 & 1.000 & .000 & 1.000 & .00 \\
\hline- & - & .871 & .129 & .997 & .003 & .000 & 1.000 & .000 & .978 & .022 & 1.000 & .000 & .000 & .995 & .005 & 1.000 & .00 \\
\hline .969 & .031 & .882 & .118 & 1.000 & .000 & .000 & .985 & .015 & .980 & .020 & .995 & .000 & .005 & 1.000 & .000 & .995 & .005 \\
\hline
\end{tabular}

$\begin{array}{llllllllllllllllllll}.954 .046 & .787 & .213 & .997 & .003 & .000 & 1.000 & .000 & 1.000 & .000 & 1.000 & .000 & .000 & 1.000 & .000 & .970 & .030\end{array}$ $\begin{array}{lllllllllllllllllllll}.990 .010 & .878 & .122 & .989 & .011 & .000 & .945 & .055 & 1.000 & .000 & 1.000 & .000 & .000 & 1.000 & .000 & .980 & .020\end{array}$ $\begin{array}{lllllllllllllllllllll}.993 & .007 & .846 & .154 & .986 .014 & .000 & 1.000 & .000 & 1.000 & .000 & 1.000 & .000 & .000 & 1.000 & .000 & .938 & .063\end{array}$ $\begin{array}{llllllllllllllllllll}.987 & .013 & .932 & .068 & .979 & .021 & .000 & .995 & .005 & 1.000 & .000 & 1.000 & .000 & .000 & 1.000 & .000 & .944 & .056\end{array}$ $\begin{array}{lllllllllllllllllllllll}.975 & .025 & .837 & .163 & .995 & .005 & .000 & .995 & .005 & 1.000 & .000 & 1.000 & .000 & .000 & 1.000 & .000 & .951 & .049\end{array}$ $\begin{array}{lllllllllllllllllllll}.977 .023 & .925 & .075 & .985 & .015 & .000 & 1.000 & .000 & 1.000 & .000 & 1.000 & .000 & .000 & 1.000 & .000 & .932 & .068\end{array}$ $\begin{array}{lllllllllllllllllll}.971 & .029 & .922 & .078 & .990 & .010 & .000 & 1.000 & .000 & .985 & .015 & 1.000 & .000 & .000 & 1.000 & .000 & .968 & .032\end{array}$ $\begin{array}{llllllllllllllllllllll}1.000 & .000 & .938 & .063 & .995 & .005 & .000 & 1.000 & .000 & 1.000 & .000 & 1.000 & .000 & .000 & 1.000 & .000 & .913 & .087\end{array}$ $\begin{array}{lllllllllllllllllllllll}.994 & .006 & .919 & .081 & .995 & .005 & .000 & 1.000 & .000 & 1.000 & .000 & 1.000 & .000 & .000 & .994 & .006 & .981 & .019\end{array}$

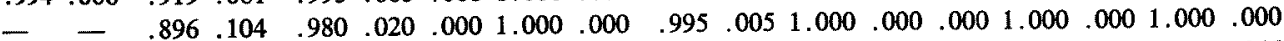
$\begin{array}{llllllllllllllllllllllll}.995 & .005 & .833 & .167 & .993 & .008 & .000 & 1.000 & .000 & 1.000 & .000 & 1.000 & .000 & .000 & 1.000 & .000 & .955 & .045\end{array}$ $\begin{array}{llllllllllllllllllllllll}.994 & .006 & .850 & .150 & .998 & .003 & .000 & 1.000 & .000 & 1.000 & .000 & .975 & .025 & .000 & 1.000 & .000 & 1.000 & .000\end{array}$ $\begin{array}{lllllllllllllllllllllllll}.980 .020 & .950 & .050 & .960 & .040 & .000 & 1.000 & .000 & 1.000 & .000 & .995 & .005 & .000 & 1.000 & .000 & .950 & .050\end{array}$

$\begin{array}{lllllllllllllllllll}.975 & .025 & .811 & .189 & .990 & .010 & .000 & 1.000 & .000 & 1.000 & .000 & 1.000 & .000 & .000 & 1.000 & .000 & .975 & .025\end{array}$

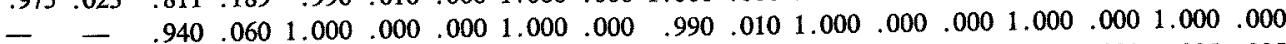

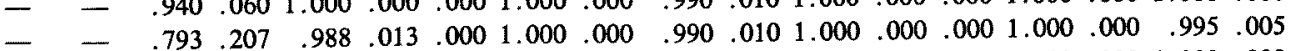
- $\quad-\quad .920 .080 \quad .990 .010 .0001 .000 .0001 .000 \quad 0001.000 \quad .000 \quad .0001 .000 \quad .0001 .000 \quad .000$

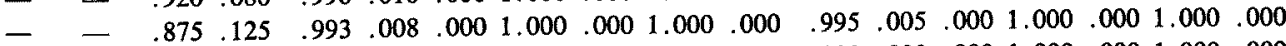

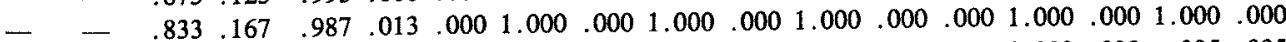

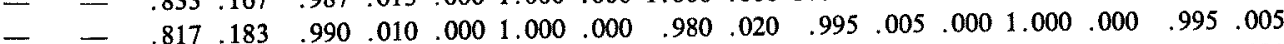
$\begin{array}{lllllllllllllllllllllll}.939 & .061 & .872 & .128 & 1.000 & .000 & .000 & 1.000 & .000 & .969 & .031 & 1.000 & .000 & .000 & 1.000 & .000 & .969 & .031\end{array}$ $\begin{array}{llllllllllllllllllll}.959 .041 & .895 & .105 & .992 & .008 & .000 & 1.000 & .000 & .989 & .011 & 1.000 & .000 & .000 & 1.000 & .000 & .929 & .071\end{array}$

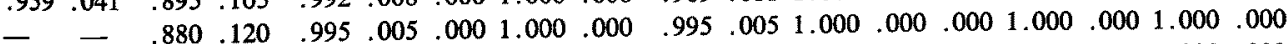
$\begin{array}{lllllllllllllllllllllll}.990 & 010 & .590 .410 & .995 & .005 & .000 & 1.000 & .000 & .965 & .035 & .990 & .010 & .000 & 1.000 & .000 & 1.000 & .000\end{array}$ $\begin{array}{lllllllllllllllllllllll}.984 & .016 & .705 & .295 & 1.000 & .000 & .000 & .990 & .010 & .995 & .005 & 1.000 & .000 & .000 & .995 & .005 & .980 & .020\end{array}$ $\begin{array}{llllllllllllllllllll}.995 & .005 & .633 & .367 & 1.000 & .000 & .000 & .990 & .010 & .990 & .010 & .990 & .010 & .000 & 1.000 & .000 & .985 & .015\end{array}$

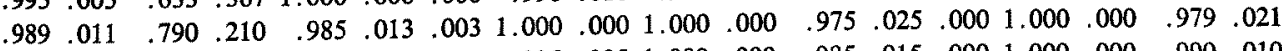

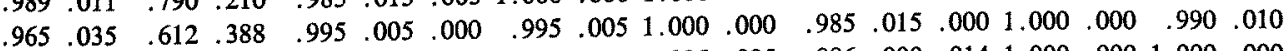
$\begin{array}{llllllllllllllllllllllll}.943 & .057 & .816 & .184 & 1.000 & .000 & .000 & .995 & .005 & .995 & .005 & .986 & .000 & .014 & 1.000 & .000 & 1.000 & .000\end{array}$ 


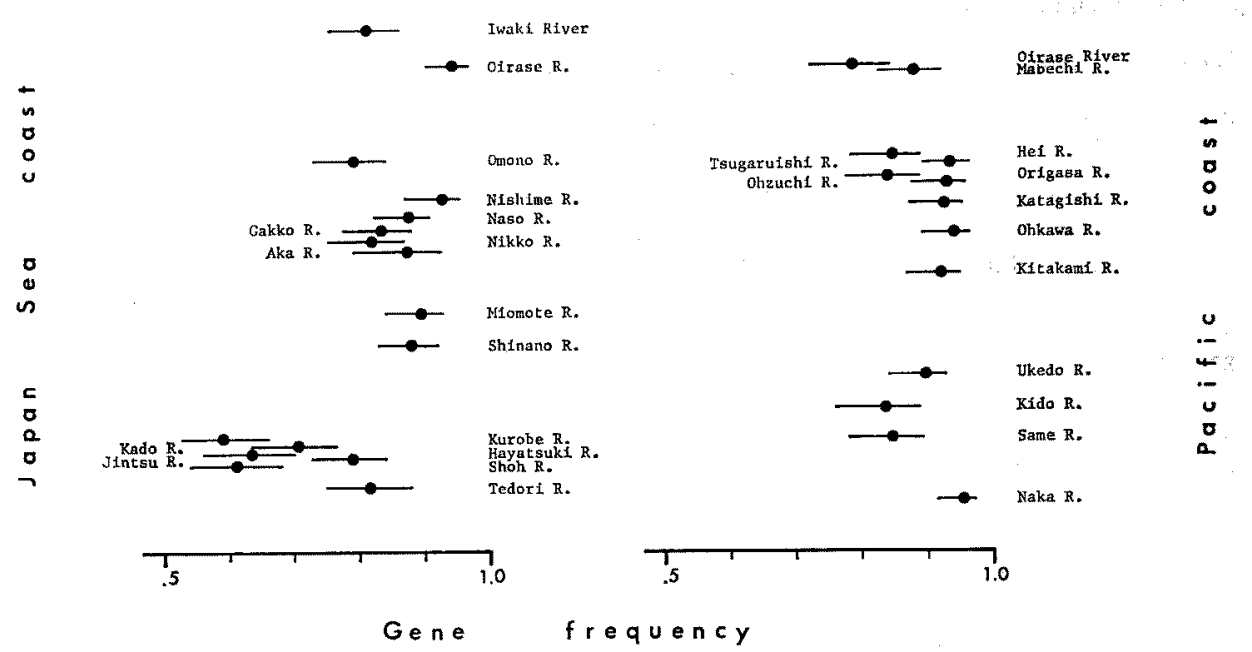

Fig. 3. Distribution of allelic frequencies and $95 \%$ confidence intervals of the $L d h-1-a$ allele in river populations on the Pacific and the Japan Sea coasts of Honshu.

frequent transplantations among rivers. However, when comparison is made within the rivers in eastern part of Hokkaido where there has been little transplantation to date, similar allelic frequencies are observed among proximal populations. It is particularly noteworthy that the $I d h$ 2-e and $M d h-B-c$ alleles which are absent in the East of Cape Erimo area and other areas are present in the Okhotsk and Nemuro areas. Furthermore similar timing of runs is observed between these adjoining areas. These similarities in the frequencies of alleles as well as in timing of runs indicate a considerable amount of gene flow within the two areas. ${ }^{\theta}$ )

On the other hand, significant differences $\left(\chi^{2}=\right.$ $20.48-39.09 ; \mathrm{P}<.01$ ) were detected at the IDH-2 locus between the Tokachi River population in the East of Cape Erimo area and the Kushiro or Bekanbeushi River population also in the East of Cape Erimo area. Incidentally the Kushiro River population bears close resemblance to the Bekanbeushi River population. This result suggests that even among rivers in the same area having similar timing of runs, the degree of gene flow varies according to the distance between river mouths.

\section{The Pacific Coast of Honshu}

A common feature of the Pacific coast populations was high frequency of the Idh-2-a allele. Geographical gradient of this allelic frequency was observed and the frequency tends to be lower proceeding southward (Fig. 2). The cline was also found for the frequency of the $L d h-1-a$ allele (Fig. 3). The frequency shows the highest value in the middle of Iwate Prefecture and tends to decrease as proceeds both north and south. This result agrees well with KIJIMA and Fusro.") However the cline of allelic frequency for $\mathrm{IDH}-3$ was not observed in the current study.

The genetic distance $(D)^{7)}$ among thirteen river populations on the Pacific coast of Honshu was calculated using twenty-two genetic loci examined in common. A dendrogram was constructed from indices of genetic distance according to unweighted paired-group method ${ }^{8)}$ (Fig. 4). This defines two major clusters of (1) northern and (2) southern populations divided by the central part of Iwate Prefecture, excepting the Mabechi River in Aomori Prefecture.

\section{The Japan Sea Coast of Honshu}

The cline for the frequency of the $I d h-2-a$ allele was also observed for chum salmon river populations on the Japan Sea coast. The frequency shows the lowest value in the south of Yamagata Prefecture and tends to increase as proceeds both north and south (Fig. 2). The eminent feature was an extremely low frequency of the $L d h-1-a$ allele in the rivers south of Toyama Prefecture (Fig. 3). Following the same procedure applied to river populations on the Pacific coast of Honshu, a dendrogram was drawn from indices of genetic distance based on twenty-two loci (Fig. 5). This clearly indicates two independent clusters of (1) northern and (2) southern populations divided 


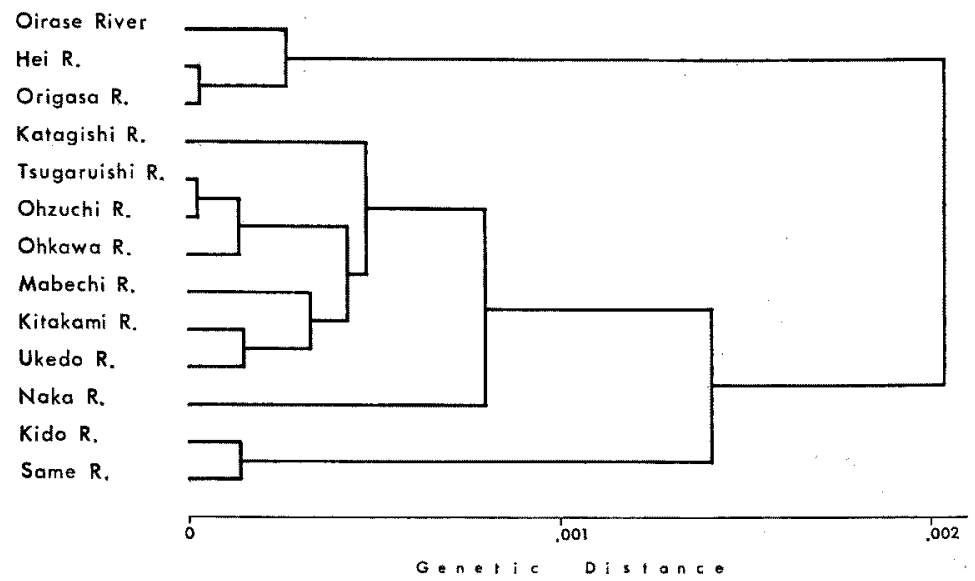

Fig.4. Dendrogram drawn from indices of genetic distance among thirteen river populations.of chum salmon on the Pacific coast of Honshu.

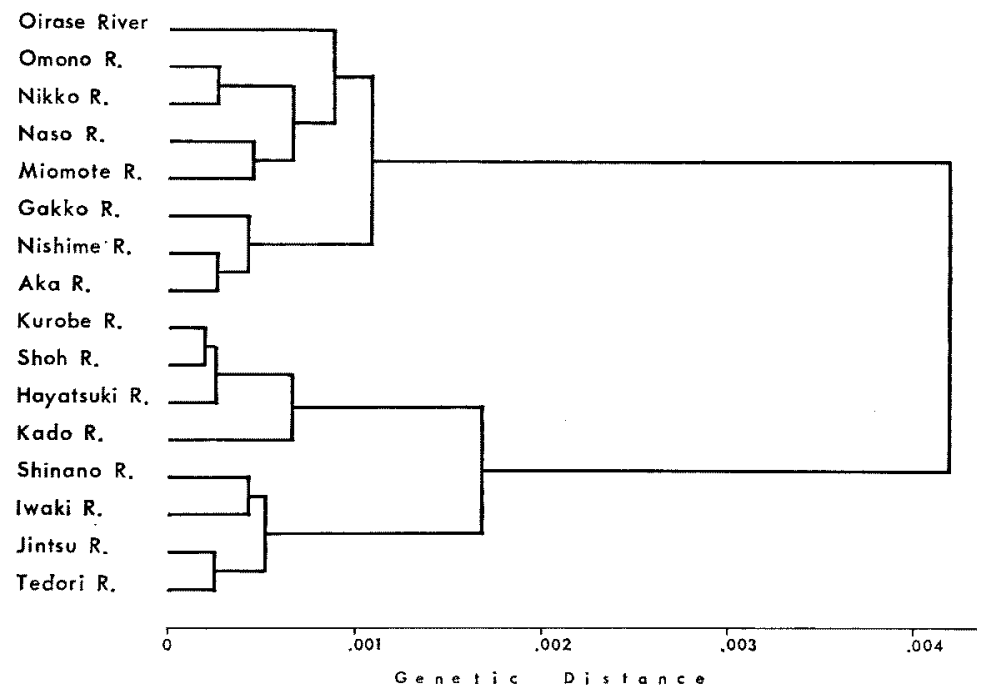

Fig. 5. Dendrogram drawn from indices of genetic distance among sixteen river populations of chum salmon on the Japan Sea coast of Honshu.

by the northern part of Niigata Prefecture. The degree of the genetic divergence was higher on the Japan Sea coast than on the Pacific coast. The result shows that the population of the Iwaki River situated northernmost is included in the southern population group. The allelic frequencies for IDH-2 and LDH-1 of the Iwaki River population were extremely different from that of the proximal river populations in Aomori and Akita Prefectures on the Japan Sea coast. In terms of the genetic distance, the population is more close to those in the eastern part of Aomori Prefecture and the northern part of Iwate Pre- fecture on the Pacific coast $(D=.00019)$.

It is worthwhile to note that even among the chum salmon river populations distributed in such a small area, geographical differences were observed in the frequencies of alleles. Fig. 6 shows resulting Japanese chum salmon regional populations presumed from the genetic feature.

\section{Discussion}

Other biological characteristics of the regional populations presumed on the basis of allelic frequencies and of their river populations, and in 


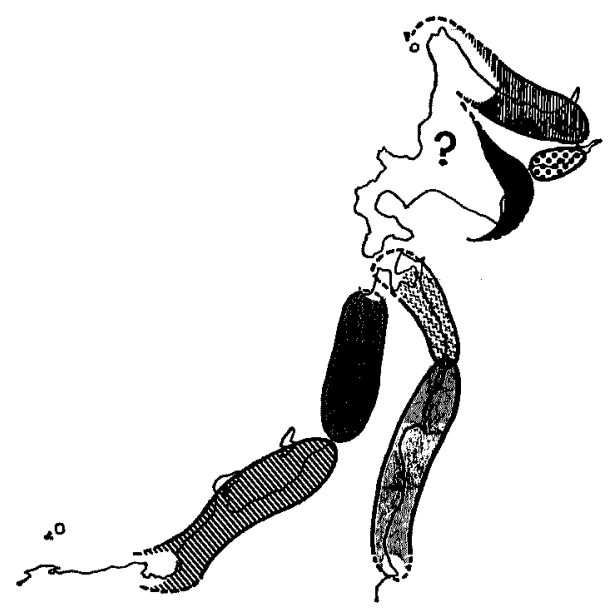

Fig. 6. Schematic diagram of regional chum salmon populations in Japan defined by gene frequency data.

particular their relation to the time of return are discussed.

Chum salmon returns to rivers approximately the same period every year and this timing has a very unique trend both on the Pacific coast and on the Japan Sea coast of Honshu. MACHIDORI ${ }^{\text {() }}$ reports that on the Japan Sea coast the time of return tends to be later proceeding southward to the border of Yamagata and Niigata Prefectures where the trend reverses and runs to streams further to the south again tend to return earlier (Fig. 7). He ascribes this phenomenon to the adaptation made by parental fish so that fry may migrate seaward at an appropriate time in the region close to the southern limits of chum salmon distribution. In this particular region, life of the chum salmon can be directly endangered by high sea temperature. Although the time of return is deferred proceeding south throughout its entire distribution, this adjustment alone cannot sustain the race. Therefore the time of return has to be advanced so that fry can safely migrate to sea in early spring while the coastal sea temperature still stands low.

This presumably brought about considerable differences in biological characteristics such as the adaptability for high sea temperature between
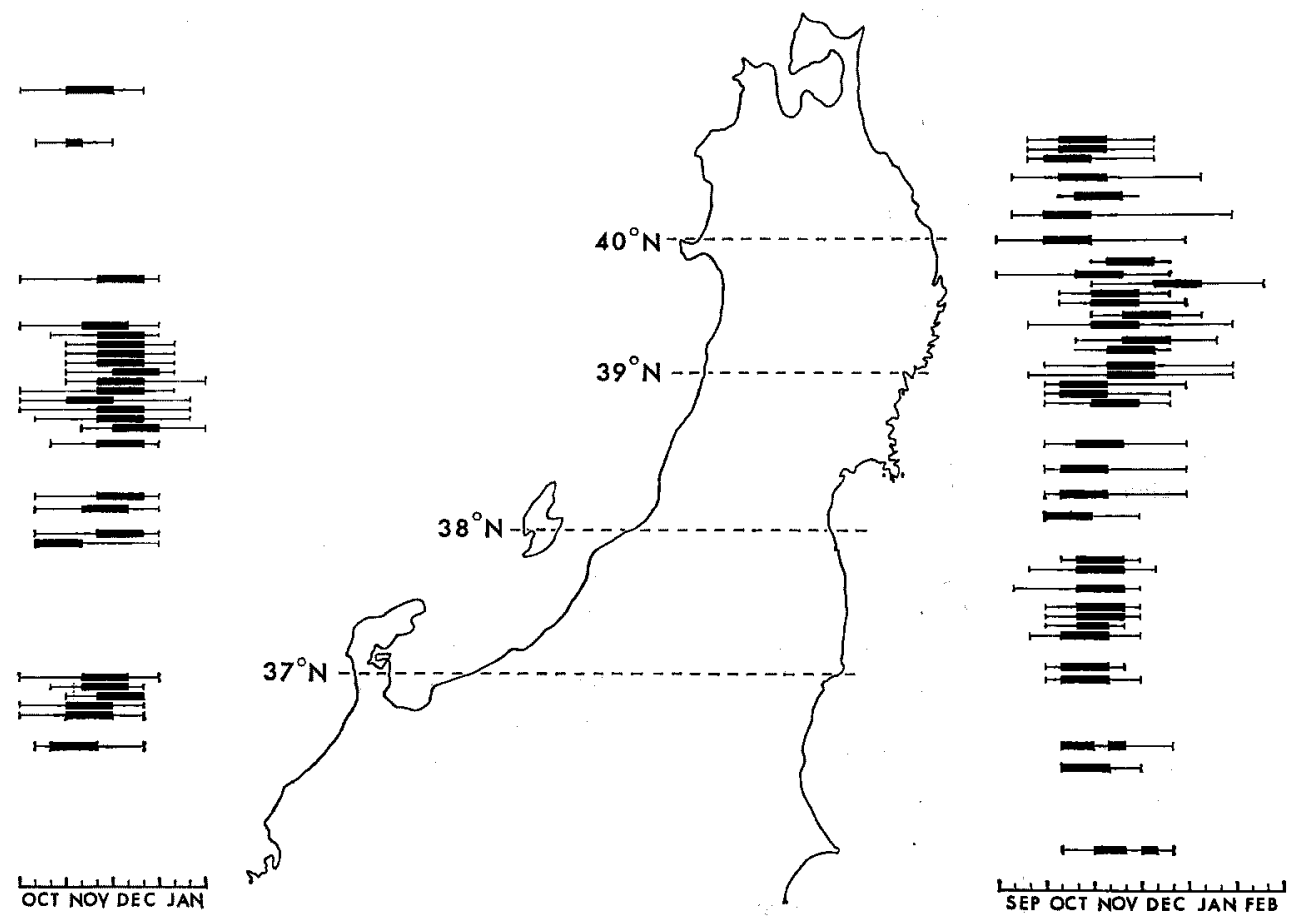

Fig. 7. Geographical distribution of the time of return and its peak period in chum salmon on the Pacific coast and the Japan Sea coast of Honshu (from Japan Salmon and Trout Resource Conservation Association). ${ }^{10}$ ) 
the populations in north and that in the southern limits of the distribution. Based on the genetic data, the chum salmon populations on the Japan Sea coast were separated into two groups, one returning to rivers south of the Shinano River and the other returning to rivers north of the Miomote River in Niigata Prefecture. This boundary coincides with a point of inflection of timing. The same trend in timing is observed on the Pacific coast. The point of inflection occurs in the middle of Iwate Prefecture where unlike on the Japan Sea coast (Fig. 7), both the rivers with early run and those with later run are distributed within a limited area. Rivers with early runs are from north, the Omoto, Hei, Sekiguchi, Origasa and Unozumai Rivers, in between which lie the Tsugaruishi and Ohzuchi Rivers with later runs. The genetic data also divide the runs on the Pacific coast into the southern and northern regional populations at a point close to the Tsugaruishi and Origasa Rivers. Furthermore early runs returning to the Hei and Origasa Rivers were included in the northern group and the later runs returning to the Tsugaruishi and Ohzuchi Rivers were included in the southern group.

An extremely close relation was observed between the time of return and the genetic structure of chum salmon river populations both on the east and the west coasts of Honshu. This indicates that genetic structure also proves chum salmon population returning to rivers south of the inflection point of timing to be independent. The point of inflection on the east coast is in somewhat different latitude from that on the west coast and it occurs to the north of the point of inflection on the west coast. Generally run on the Pacific coast proceeds runs on the Japan Sea coast by twenty to thirty days (Fig. 7). These phenomena are closely related to difference in environment between the two coasts. For instance, coastal sea temperature on the Japan Sea coast tends to be higher than on the Pacific coast from the end of September to November when parental fish start to return and conversely it tends to be lower on the Japan Sea coast in the region close to the southern limits of the distribution from January to February when fry migrate to sea. ${ }^{11}$ )

The cline was observed between the east and the west coasts of Honshu for the frequency of the Idh-2- $a$ allele. The cline for the allelic frequency is well known in many organisms and several factors including adaptability of gene to the environment are considered to be re- levant. ${ }^{12,13)}$ In case of the observed cline for the Idh-2- $a$ allele of each river population in Honshu, the trend of variation on the Pacific coast is reverse from that on the Japan Sea coast. Therefore it is hard to ascribe this phenomenon to the different adaptability of this allele. Although it is presumably related to the effects of many years of straying to proximal rivers, the causes have not yet been determined.

The author in the above discussed the allelic frequencies of the chum salmon river populations in Japan and stated that there are several regional populations. When the allelic frequencies of each regional population are compared with that of the populations returning to the Continent of North America or to the far east regions of the U.S.S.R., a common feature among the Japanese populations becomes evident. For instance, chum salmon populations in North America are not polymorphic for MDH-B and the populations south of British Columbia are not polymorphic for LDH-1,2) while Asiatic populations (including the U.S.S.R. and Japan) are polymorphic for MDH-B although at low frequencies. When comparison is made between the populations in Japan and those in the U.S.S.R., the frequency of polymorphism for $\alpha$-GDH-2 and that for the Idh-2-c allele are higher in the latter. ${ }^{\left({ }^{2}\right.}$ These phenomena are assumed to be a reflection of gene flow among chum salmon river populations within a certain geographic range.

Intermingling of River Populations due to Transplantation and the Effects of Transplantation

Rivers in Japan have been heavily planted in connection with artificial propagation. It has been already pointed out by the author that this very likely produced a certain effect on the allelic frequencies of the native river populations. Due consideration needs to be given to this effect in investigating genetic traits and geographic differences of each river population. Transplantation attempted in Japan to date and its effects are outlined.

In Honshu, chum salmon has been most frequently transplanted to rivers in and close to the southern limits of the distribution where the stock size is small. As there are only few rivers with sufficient amount of eggs to supply in Honshu, the main sources of eggs have been the rivers in Hokkaido in addition to a very few rivers in Iwate and Yamagata Prefectures. Eggs have been transferred to rivers with small stock size 
every year. However the donor stream is not always the same as the supply and demand fluctuate yearly. Donor streams are not ever recorded with accuracy in some rivers. Despite many years of large-scale transplantations, the trend of particular increase in returns was hardly observed. The question remains as to whether the planted stock did in effect return to new rivers and contribute to reproduction. Not a few rivers are even considered to be barely sustaining a certain level of returns by continuing to introduce large number of eggs every year.

The trend of planted populations in some of the rivers is discussed in the following section. In general, the original timing tends to persist in the transplanted fish. As they seem to be quite conservative with this trait, it permits the monitoring of the trend of the transplanted stock provided eggs are introduced from rivers having considerably different timing. When fish returning late was transplanted to the Ohkawa River in Miyagi Prefecture, ${ }^{14)}$ the Omoto, Hei and Origasa Rivers in Iwate Prefecture, ${ }^{15)}$ a new late peak was established three or four years after transplantation. In the Ohkawa River this late peak eventually disappeared, and it is not clear to what extent the transplanted stock ultimately contributed to the reproduction, whereas in other rivers, a new second peak is still present. However as the large-scale transplantation has been carried out every year in these rivers, it is doubtful whether the transplanted stock in effect repeats reproduction effectively. On the other hand, in the Tokachi River in Hokkaido, a new late peak has been established for over three generations. ${ }^{10)}$ The later group has distinct allelic frequency from that of the native group which suggests that both populations do not easily intermingle.

The change in seasonal distribution of spawning run resulting from transplantation tends to disappear eventually and it is extremely rare that this change persists for such a long period of time as in the Tokachi River. When transplanting runs having similar timing to native runs, such change in seasonal distribution of spawning run can not be expected.

The effects of transplantation have not been precisely evaluated. In the following section, the actual effects of the transplantations in the past are discussed. A general characteristic of annual chum salmon runs returning to different rivers is their definite timing. This trait of dis- tinct timing tends to persist in the transplanted fish as noted in the above. This indicates that these traits acquired for the purpose of efficient reproduction in particular river would not easily alter in a different environment. A good example of this is a later run of the Tokachi River which still keeps the original timing after three generations have passed since the transplantation. ${ }^{16)}$ : River populations even in a relatively small area of Honshu acquired various traits well adapted to their environment. If indeed these traits would hardly change after transplantation, reproduction in a different environment will become very inefficient particularly when a difference is significant. Physical environment such as temperature in river or coastal area and sunshine usually differs more between north and south than between east and west. These factors cumulatively indicate that it is nearly impossible to expect a good result from transplantation from latitudinally distant rivers. Effective transplantation probably requires eggs from proximal rivers. However, rivers in and close to the southern limits of chum salmon distribution do not have sufficient number of eggs and the main source of supply has been rivers in Iwate, Yamagata and Hokkaido. The observed genetic divergence between the northern and southern groups both on the Pacific coast and on the Japan Sea coast raises a doubt on the effectiveness of the past transplantations. The same doubt is also raised as cline was observed in some of the allelic frequencies despite the largescale transplantations carried out in may rivers in Honshu to date.

On the other hand in Hokkaido, almost all the eggs are transferred from rivers in Hokkaido. Transfer is in a way from rivers in east to those in west and vice versa with a few exceptions. Unlike in Honshu, a phenomenon presumed to be a result of transplantation such as the absence of distinct genetic feature within regional populations was observed in the structure of river populations in Hokkaido. As the period of time and scale of transplantation are different, it is not appropriate to compare Hokkaido populations with Honshu populations unconditionally. Neverthless the difference in effects of transplantation between the two is presumed to be significant.

A donor stream in most cases has been chosen merely according to a supply and demand situation of eggs, ignoring biological characteristics of eggs. In future, eggs most suited to a river should be selected for more effective transplantations. 


\section{References}

1) F. Neave, T. Yonemori, and R. G. Bakkala: Bull. INPFC, 35, 1-79 (1976).

2) T. OKaZAKI: Bull. Japan. Soc. Sci. Fish., 47, 507-514 (1981).

3) K. Numachi and R. Sato: Genetic Variants of Enzymes and Genetic Compositions of Chum Salmon (Oncorhynchus keta), U.S. Japan Coop. Sci. Programme, 1970, pp. 42-76.

4) A. KuJimA and Y. Fujo: Bull. Japan. Soc. Sci. Fish., 45, 287-295 (1979).

5) M. J. Siciliano and C. R. Shaw: Chromatographic and Electrophoretic Techniques, Vol. 2, Heinemann, London, 1976, pp. 185-209.

6) T. OKazakr: Bull. Far Seas Fish. Res. Lab., 17, 141-157 (1979).

7) M. Ner: Molecular Population Genetics and Evolution, North-Holland, New York, 1975, pp.
175-209.

8) P. H. SNeath and R. R. Sokal: Numerical Taxonomy, Freeman, San Francisco, 1973, pp. 188-308.

9) S. MACHIDORI: Sake to Masu, 20, 6-23 (1978).

10) Japan Salmon and Trout Resource Conservation Association: Analysis of the Present Status of Reproduction and Use of Chum Salmon Stock in Japan, 1976, pp. 1-168.

11) Japan Hydrographic Association: Marine Environmental Atlas-Northern Pacific Ocean II, 1978, pp. 1-157.

12) R. K. KoeHN: Science, 163, 943-944 (1969).

13) T. W. Moon and P. W. Hochachka: Comp. Biochem., 42B, 725-730 (1972).

14) Y. Nose: Kagaku to Seibutsu, 8, 738-744 (1970).

15) S. Shirahata: Sakana, 17, 26-34 (1976).

16) T. OKazAKI: Bull. Far Seas Fish. Res. Lab., 16, 121-128 (1978). 